\title{
GENERALISASI BIMBINGAN KONSELING PRIBADI DAN SOSIAL UNTUK REMAJA DI ERA MILENIAL
}

\author{
Akhmad Ramidi \& Ishak Hariyanto \\ e-mail: akhmadramidi765@gmail.com \\ email: ishakharianto@yahoo.co.id \\ Mahasiswa UIN Sunan Kalijaga Yogyakarta\& \\ Pengajar Filsafat Fakultas Dakwah dan IImu Komunikasi UIN Mataram
}

\begin{abstract}
The purpose of this paper is to describe the reality of youth in the millennial era about the challenges of the times or the influence of globalization. Threats to adolescents are very complex and how to optimize their strengths and opportunities. In this article try to discuss criminal cases that have occurred since 2014-2017 based on historical facts from the Directorate of Political and Security Statistics Indonesia, it turns out the results of the research are crime data and those who are exposed to crimes continue to increase from years previous. Therefore, the author tries to discuss the role of personal and social counselling as a model for developing or minimizing these crimes. The method used is the literature method and descriptive method. The literature method is the result of someone's writing from the article and tries to distinguish the results from this article. While the descriptive method is data or results of research from one institution to another. The results of the analysis in this article use a group counselling approach in the view of Alfred Adler and require several stages, namely: a. the stage of forming and maintaining relationships, b. stage of analysis and assessment, c. insight stage and, d. back orientation stage.
\end{abstract}

Keywords: Generalization of Guidance, Personal Counseling, Millennial Adolescence 


\begin{abstract}
Abstrak
Tujuan penulisan ini adalah untuk mendeskripsikan kehidupan realitas remaja di era milenial tentang tantangan zaman atau pengaruh globalisasi. Ancaman bagi remaja sangat kompleks dan bagaimana mengoptimalkan kekuatan dan peluangnya. Dalam artikel ini mencoba membahas kasus-kasus kriminalitas yang sudah terjadi semenjak dari tahun 2014-2017 berdasarkan fakta historis yang berasal dariDirektorat Statistik Politik dan Keamanan Indonesia, ternyata hasil dari penelitiannya tersebut adalah data kejahatan dan yang terkena kejahatan terus meningkat dari dari tahun-tahun sebelumnya. Oleh karenanya, penulis mencoba akan membahas peran bimbingan konseling pribadi dan sosial sebagai sebuah model untuk mengembangkan atau meminimalisir kejahatan-kejahatan tersebut. Adapun metode yang digunakan adalah metode literatur dan metode deskriptif. Metode literatur yaitu hasil tulisan seseorang dari artikel dan mencoba membedakan hasil dari artikel ini. Sedangkan metode deskriptif yaitu data atau hasil penelitian dari suatu lembaga ke lembaga lainnya.Adapun hasil analisis dalam artikel ini menggunakan pendekatan konseling kelompok dalam pandangan Alfred Adler dan memerlukan beberapa tahap yaitu: a. tahap membentuk dan memelihara hubungan, b. tahap analisis dan penilaian, c. tahap wawasan dan, d. tahap orientasi kembali.
\end{abstract}

Kata kunci: Generalisasi Bimbingan, Konseling Pribadi, Remaja Milenial 


\section{A. Pendahuluan}

Hadirnya era globalisas telah membuka wawasan dan kesadaran masyarakat, betapa masa ini membawa harapan dan kecemasan. Kecemasan disebabkan selain karena adanya perubahan dan tantangan, juga banyaknya tayangan di media yang tidak semuanya sesuai dengan nilai moral dan agama, sehingga tidak menutup kemungkinan dapat mengubah karakter yang dimiliki oleh seorang remaja. Perubahan dan tantangan merupakan suatu yang mesti terjadi dan tidak dapat dihindari oleh siapapun orang selama dia masih tinggal di bumi hanya bagaimana menyikapinya, supaya berbagai perubahan dan tantangan itu dapat dimanfaatkan menjadi peluang. Seorang remaja adalah sosok yang sangat berperan dalam menghadapi proses pembangunan bangsa dan mental, banyak sekali harapan yang diletakkan dipundak mereka. Meskipun banyak tantangan yang dihadapi oleh remaja, terutama mencari jati diri dan tantangan hidup yang beragam. Dalam menghadapi dunia dan tantangan di era modern ini, kita tidak bisa melewatinya sendiri, perbanyak teman, sahabat adalah kunci unutuk memecahkan teka-teki di era sekarang ini, bergaul dan mempererat hubungan adalah kunci untuk menaklukan kecemasan-kecemasan pada diri pribadi seseorang.

Semenjak kemerdekaan bangsa Indonesia senantiasa bertekad untuk memperjuangkan dan membangun sumber daya manusia menuju bangsa yang cerdas, maju, adil dan makmur, baik secara spiritual dan materil. Dalam upaya membangun dan pengembangan sumber daya manusia di segala bidang terus meningkat, karena bangsa kita sangat tertinggal dan mengejar ketertinggalan yang amat parah yang kita warisi akibat zaman penjajahan yang sangat lama, kita ingin segera bangsa Indonesia lebih maju dari bangsa-bangsa yang lain. Oleh karena itu, pada tahun 1970-an dicanangkan upaya "akselerasi-modernisasi" dengan kecepatan yang semakin mengikat kita untuk memodernisasikan bangsa Indonesia $^{18}$. Jika kita bandingkan dengan Negara-negara lain seperti Inggris, Rusia, Amerika Serikat, Korea Utara dan Negara lain-lain secara sumber daya manusia kita sudah tertinggal jauh.

Dunia terus berkembang khususnya di Eropa, perubahan dan perkembangannya dari zaman pertanian ke industrialisasi menuju zaman informasi yang seakan-akan

18 Prayitno Dan Erman Amti, DasarDasar Bimbingan Konseling, (Jakarta: Pt Rineka Cipta, 2013), 3. 
menggiringsuatuopini, pendapatuntuk bagaimana membangun peradaban yang baik pada masyarakat, persaingan begitu massif untuk menemukan dan menciptakan teknologi-teknologi yang berkualitas sehingga dampaknya sangat mempengaruhi realitas kehidupan masyarakat terutama remaja di era milenial ini.

Arus dunia modernisasi membawa dampak yang positif dan negatif bagi kehidupan remaja. Di satu sisi, modernisasi menyiapkan berbagai kemudahan baik dalam komunikasi dan transportasi. Namun, di sisi lain ternyata modernisasi melahirkan dampakyangmerugikanumatmanusia. Problematika semakin kompleks, baik secara personal maupun secara sosial, manusia modern telah terpedaya oleh produk pemikirannya sendiri karena tidak mampu mengontrol efek sampingnya yaitu rusaknya lingkungan yang memperkeruh keamanan dan kenyamanan hidupnya sendiri ${ }^{19}$.

\section{Ancaman dan kelemahan remaja di era milenial}

Bahahayanya perkelahian masal (tawuran), bahayanya narkoba, minuman keras, pergaulan bebas ${ }^{20}$, pembunuhan atau bunuh diri,

19 Farid Mashudi, Psikologi Konseling, (Jogjakarta: Ircisod Penerbit, 2012), 171.

20 Syamsu Yusuf, Bimbingan Dan Koseling Perkembangan: Suatu Pendekatan Komprehensif, (Bandung: PT. Refika Aditama, 2017), 95. pemerkosaan, pelecehan seksual, aborsi, pencurian dan serta kasus-kasus kriminalitas yang setiap hari bahkan setiap jam kita dengar, yang selalu mengisi berita-berita baik di media cetak dan maupun media online. Tentu, ini adalah kesedihan, kegelisahan setiap orang termasuk para akademisi, pemerintah dan ilmuan yang belum mampu mengatasi atau menemukan obat terhadap fenomena-fenomena sosial kita saat ini.

Menurut data statistik tahun 2017, selama periode tahun 2014-2016, jumlah kejadian kejahatan atau tindak kriminalitas di Indonesia cendrung meningkat, data kepolisian republik Indonesia(polri) juga memperlihatkan jumlah kejadian kejahatan pada tahun 2014 sebanyak 325.317 kasus, menurun menjadi sebanyak 352.936 kasus pada tahun 2015 dan meningkat pada tahun 2016 menjadi 357.197 kasus. Sementara itu, jumlah orang yang terkena tindak kejahatan setiap 100.000 penduduk di perkirakan sebanyak 131 orang pada tahun 2014 sedangkan pada tahun 2015 dan 2016 sebanyak 140 orang.

Untuk lebih jelasnya, melihat jumlah kejahatan dan tingkat risiko terkena kejahatan pada tahun 2014 sampai 2016 sebagai berikut: 

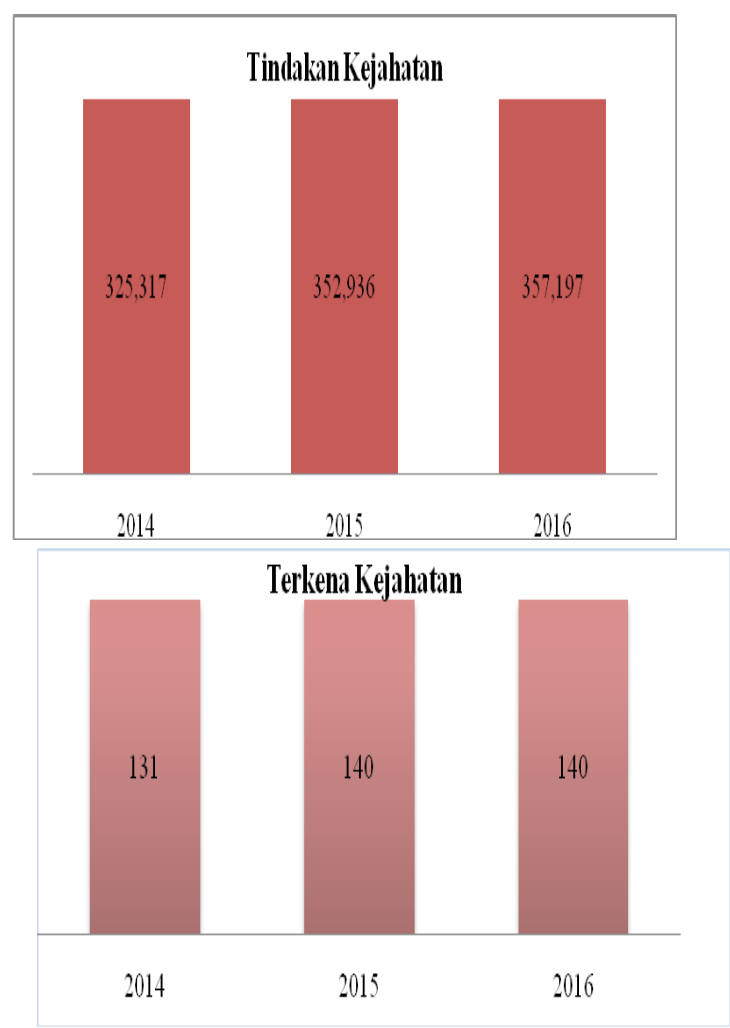

Jumlah kejahatan (crime total) dan tingkat risiko yang terkena kejahatan (crime rate) pada tahun 2014-2016

Kejadian kejahatan dan kriminalitasnya selama periode 2014-2106 juga menunjukkan pola perkembangan yang serupa. Selang waktu terjadinya tindakan kejahatan (crime clock) sebesar 00.01'36" (1 menit 36 detik) pada tahun 2014 dan menjadi 00.01'28' (1 menit 28 detik) pada tahun 2016. Interval waktu yang semakin pendek menunjukkan intensitas kejadian tindakan kejahatan yang semmangkin meningkat dan sebaliknya.

Dari segi jumlah kejahatan pada level provinsi atau polda, selama tahun 2016 polda metro jaya mencatat mencatat jumlah kejahatan terbanyak (43.3842 kasus) dan disusul oleh pada polda sumtra utara (37.102 kasus), dan polda jawa barat (29.351 kasus) sedangkan polda Maluku, kepulauan Bangka Belitung dan Maluku utara dengan jumlah kejadian kejahatan berturut-turut sebanyak 2.559;2.094 dan 1.096 merupakan tiga polda dengan jumlah kejahatan paling sedikit. Dan perlu menjadi catatan bahwa jumlah kejahatan bisa di pengaruhi dan jumlah penduduk di suatu wilayah. Adapun data atau jumlah tindakan kejahatan berdasarkan wilayah di suatu provinsi adalah sebagai berikut:

\begin{tabular}{|l|l|l|}
\hline NO & $\begin{array}{l}\text { N a m m a } \\
\text { Provin s / } \\
\text { Wilayah }\end{array}$ & $\begin{array}{l}\text { Angka/Jumlah } \\
\text { Kejahatan }\end{array}$ \\
\hline 1 & Metro jaya & $\begin{array}{l}43.842 \quad \text { kasus/ } \\
\text { kejahatan }\end{array}$ \\
\hline 2 & $\begin{array}{l}\text { S u m a t e r a } \\
\text { utara }\end{array}$ & $\begin{array}{l}\text { 37.102 kasus/ } \\
\text { kejahatan }\end{array}$ \\
\hline 3 & Jawa barat & $\begin{array}{l}29.351 \quad \text { kasus/ } \\
\text { kejahatan }\end{array}$ \\
\hline 4 & Jawa timur & $\begin{array}{l}28.902 \\
\text { kejahatan }\end{array}$ \\
\hline 5 & $\begin{array}{l}\text { S u m a t e r a } \\
\text { selatan }\end{array}$ & $\begin{array}{l}20.368 \\
\text { kejahatan }\end{array}$ \\
\hline 6 & $\begin{array}{l}\text { S u } 1 \text { a w e s i } \\
\text { selatan }\end{array}$ & $\begin{array}{l}15.071 \\
\text { kejahatan }\end{array}$ \\
\hline 7 & $\begin{array}{l}\text { S u m a t e r a } \\
\text { barat }\end{array}$ & $\begin{array}{l}14.921 \\
\text { kejahatan }\end{array}$ \\
\hline 8 & kasus/ \\
\hline
\end{tabular}




\begin{tabular}{|c|c|c|c|}
\hline 9 & Lampung & $\begin{array}{l}10.485 \\
\text { kejahatan }\end{array}$ & kasus / \\
\hline 10 & $\begin{array}{l}\text { S u l a w e s i } \\
\text { utara }\end{array}$ & $\begin{array}{l}9.923 \\
\text { kejahatan }\end{array}$ & kasus / \\
\hline 11 & Aceh & $\begin{array}{l}9.646 \\
\text { kejahatan }\end{array}$ & kasus / \\
\hline 12 & $\begin{array}{l}\text { S u l a w e s i } \\
\text { tengah }\end{array}$ & $\begin{array}{l}9.602 \\
\text { kejahatan }\end{array}$ & kasus / \\
\hline 13 & Jambi & $\begin{array}{l}9.424 \\
\text { kejahatan }\end{array}$ & kasus / \\
\hline 14 & $\begin{array}{l}\text { Kalimantan } \\
\text { timur }\end{array}$ & $\begin{array}{l}8.896 \\
\text { kejahatan }\end{array}$ & kasus / \\
\hline 15 & Riau & $\begin{array}{l}8.520 \\
\text { kejahatan }\end{array}$ & kasus / \\
\hline 16 & $\begin{array}{l}\text { D } \\
\text { Yogyakarta }\end{array}$ & $\begin{array}{l}8.348 \\
\text { kejahatan }\end{array}$ & kasus / \\
\hline 17 & Papua & $\begin{array}{l}8.103 \\
\text { kejahatan }\end{array}$ & kasus / \\
\hline 18 & $\begin{array}{l}N \quad u \quad s \quad a \\
t \text { e n g g a r a } \\
\text { timur }\end{array}$ & $\begin{array}{l}7.813 \\
\text { kejahatan }\end{array}$ & kasus/ \\
\hline 19 & $\begin{array}{l}\mathrm{N} u \quad s \quad a \\
t \text { e } n g g \text { a } a \\
\text { barat }\end{array}$ & $\begin{array}{l}7.779 \\
\text { kejahatan }\end{array}$ & kasus / \\
\hline 20 & $\begin{array}{l}\text { Kalimantan } \\
\text { barat }\end{array}$ & $\begin{array}{l}7.311 \\
\text { kejahatan }\end{array}$ & kasus / \\
\hline 21 & $\begin{array}{l}\text { Kalimantan } \\
\text { selatan }\end{array}$ & $\begin{array}{l}7.211 \\
\text { kejahatan }\end{array}$ & kasus / \\
\hline 22 & Bengkulu & $\begin{array}{l}5.904 \\
\text { kejahatan }\end{array}$ & kasus / \\
\hline 23 & $\begin{array}{l}\text { Ke pula un } \\
\text { riau }\end{array}$ & $\begin{array}{l}4.885 \\
\text { kejahatan }\end{array}$ & kasus / \\
\hline 24 & Bali & $\begin{array}{l}4.764 \\
\text { kejahatan }\end{array}$ & kasus/ \\
\hline 25 & Banten & $\begin{array}{l}4.570 \\
\text { kejahatan }\end{array}$ & kasus / \\
\hline 26 & Gorontalo & $\begin{array}{l}3.763 \\
\text { kejahatan }\end{array}$ & kasus / \\
\hline
\end{tabular}

\begin{tabular}{|c|c|c|c|}
\hline 27 & $\begin{array}{l}\text { S u l a w e s i } \\
\text { tenggara }\end{array}$ & $\begin{array}{l}3.756 \\
\text { kejahatan }\end{array}$ & kasus / \\
\hline 28 & $\begin{array}{l}\text { Kalimantan } \\
\text { tengah }\end{array}$ & $\begin{array}{l}3.712 \\
\text { kejahatan }\end{array}$ & kasus / \\
\hline 29 & Papua barat & $\begin{array}{l}3.123 \\
\text { kejahatan }\end{array}$ & kasus / \\
\hline 30 & Maluku & $\begin{array}{l}2.559 \\
\text { kejahatan }\end{array}$ & kasus / \\
\hline 31 & $\begin{array}{l}\text { Kepulauan } \\
\mathrm{B} \text { a n g k a } \\
\text { blitung }\end{array}$ & $\begin{array}{l}2.094 \\
\text { kejahatan }\end{array}$ & kasus / \\
\hline 32 & $\begin{array}{l}\text { M a } 1 \mathrm{u} \mathrm{k} \mathrm{u} \\
\text { utara }\end{array}$ & $\begin{array}{l}1.096 \\
\text { kejahatan }\end{array}$ & kasus/ \\
\hline
\end{tabular}

Tindakan kejahatan di suatu wilayah dari tahun 2014-206

\begin{tabular}{|l|l|l|}
\hline No & $\begin{array}{l}\text { N a m a } \\
\text { P r i n s i } \\
\text { Wilayah }\end{array}$ & $\begin{array}{l}\text { T e } \mathbf{~ k ~ e ~} \mathbf{n} \text { a } \\
\text { Kejahatan }\end{array}$ \\
\hline 1 & Papua barat & 396 crime rate \\
\hline 2 & Sulawesi utara & 343 crime rate \\
\hline 3 & $\begin{array}{l}\text { S u l a w e s i } \\
\text { tengah }\end{array}$ & 326 crime rate \\
\hline 4 & Gorontalo & 305 crime rate \\
\hline 5 & Bengkulu & 298 crime rate \\
\hline 6 & $\begin{array}{l}\text { S u m a t e r a } \\
\text { barat }\end{array}$ & 283 crime rate \\
\hline 7 & Jambi & 274 crime rate \\
\hline 8 & $\begin{array}{l}\text { S u m a t e r a } \\
\text { utara }\end{array}$ & 258 crime rate \\
\hline 9 & $\begin{array}{l}\text { Kaliman tan } \\
\text { timur }\end{array}$ & 252 crime rate \\
\hline 10 & $\begin{array}{l}\text { S u m e t r a } \\
\text { selatan }\end{array}$ & 250 crime rate \\
\hline 11 & Papua & 236 crime rate \\
\hline 12 & Kepulauan riau & 236 crime rate \\
\hline
\end{tabular}




\begin{tabular}{|c|c|c|}
\hline 13 & DI Yogyakarta & 211 crime rate \\
\hline 14 & Aceh & 194 crime rate \\
\hline 15 & Metro jaya & 169 crime rate \\
\hline 16 & $\begin{array}{l}\text { Nusa tenggara } \\
\text { barat }\end{array}$ & 166 crime rate \\
\hline 17 & $\begin{array}{l}\text { Kalimantan } \\
\text { selatan }\end{array}$ & 166 crime rate \\
\hline 18 & $\begin{array}{l}\text { S u l a w e s i } \\
\text { selatan }\end{array}$ & 166 crime rate \\
\hline 19 & $\begin{array}{l}\text { Kalimantan } \\
\text { barat }\end{array}$ & 147 crime rate \\
\hline 20 & $\begin{array}{l}\text { Nusa tenggara } \\
\text { timur }\end{array}$ & 146 crime rate \\
\hline 21 & $\begin{array}{l}\text { K e p u l a u a n } \\
\text { Bangka bliting }\end{array}$ & 139 crime rate \\
\hline 22 & $\begin{array}{l}\text { S u la w e s i } \\
\text { tenggara }\end{array}$ & 135 crime rate \\
\hline 23 & Lampung & 131 crime rate \\
\hline 23 & Riau & 124 crime rate \\
\hline 25 & Maluku & 122 crime rate \\
\hline 26 & $\begin{array}{l}\text { Kalim antan } \\
\text { tengah }\end{array}$ & 118 crime rate \\
\hline 27 & Bali & 106 crime rate \\
\hline 28 & Banten & 87 crime rate \\
\hline 29 & Maluku utara & 69 crime rate \\
\hline 30 & Jawa barat & 68 crime rate \\
\hline 31 & Jawa timur & 52 crime rate \\
\hline 32 & Jawa tengah & 39 crime rate \\
\hline
\end{tabular}

Orang terkena tindakan kejahatan dari tahun 2014-2016
Jumlah kejahatan (crime total) dan tingkat risiko yang terkena kejahatan (crime rate) hanya menggambarkan fenomena kejahatan secara umum. Angka kejahatan tersebut dapat di antisipasi oleh remaja dan masyarakat untuk menertibkan keamanan, kenyamanan bagi banyak orang. Publikasi ini mengelompokkan jenisjenis kejahatan berdasarkan kriteria sebagai berikut:

Target dari kejadian kejahatan terhadap(orang, hartabenda, ketertiban umum, Negara dan sebagainya.

Tingkat keseriusan kejahatan terhadap (nyawa sesama, kejahatan terhadap fisik, kejahatan terhadap hak milik orang lain dan sebagainya

Bagaimana kejahatan tersebut dilakukanterhadap(kejahatanterhadap milik orang lain atau milik orang lain dengan kekerasan, kejahatan terhadap hak milik atau barang tanpa kekerasan seperti pencurian dan sebagainya. ${ }^{21}$

\section{Optimalisasi kekuatan dan peluang remaja di era milenial}

Dari kejahatan-kejahatan yang di gambarkan secara umum, konflik tersebut adalah bagian dari kehidupan realitas kita sekarang ini. Konflik terjadi ketika seseorang individu merasakan ada yang mengusik atau

21 Naskah Sub Direktorat Statistik Politik Dan Keamanan, Jakarta: Badan Pusat Statistik Indonesia, 2017, 17-22. 
mengganggu langkahnya menuju suatu pencapaian kebetuhan ${ }^{22}$.Di sinilah, kita membutuhkan peran seorang remaja yang harus ikut andil dan mengoptilmakan kekuatannya dan tidak ikut terjebak dalam situasi tersebut.

Untuk mengoptimalkan atau membangkitkan potensi remaja di era millineal menurut Jazak Yus Afriansyah setidakny ada empat cara, model pengembangan atau teknik yang harus dipahami dan di kuasai oleh leader generasi $\mathrm{X}$ dan $\mathrm{Y}$ dalam memanfaatkan generasi $Z$ mencapai kinerja yang diharapkan yaitu mereka mampu atau mau melakukan dan mereka mau terus berprestasi bersama lembaga-lembaga yang mempunyai legitimasi hukum atau tidak (korporasi). Adapun cara tersebut sebagai berikut:

Membangkitkan mereka dengan cara encouraging ideas atau mendorong mereka melakukan dan menyampaikan ide-ide kreatif dan inovatifnya, karena generasi millineal sangat terbuka (loyal) terhadap kepentingan mereka.

Memberikan sentuhan modifying ideas atau modifikasi ide-ide mereka, karena kendatipun generasi milenial sangat kreatif dan inovatif dan jelas ide-ide mereka applicable atau bisa

22 Samuel T. Gladding, Konseling Profesi rang Menyeluruh, (Jakarta Barat:PT Indeks, 2015), 24. dilaksanakan. Dengan kata lain terkadang ada ide-ide mereka yang tidak realistis dan tidak cocok dengan zaman atau kondisi kita sekarang ini.

Menghadirkan umpan balik terhadap mereka (providing feedback) jelas ini sangat berguna untuk memastikan apakah generasi milenial ini masih mempunyai motivasi yang sangat tinggi dan mendengarkan mereka untuk melakukan kolaborasi supaya semangat mereka tidak lemah.

Memberikan mereka alternatif dan arahan atau perintah (give alternative and limited direction) dengan cara ini juga dapat digunakan sebagai pengobar semangat pada remaja yang apabila masih malas-malasan dan memberikan mereka kesempatan untuk berpikir melakukan sesuatu dengan model kerangka berpikirnya. ${ }^{23}$

\section{Remaja di era milenial dan peran BK pribadi-sosial}

Generasi milenial adalah generasi yang mahir di dalam menggunakan teknologi. Peran dan fungsinya sebagai generasi milenial harus bisa tercipta sebagai generasi agent of change dan harus menjadi orang yang optimis dan tidak mudah untuk berhenti melakukukan langkah-langkah dalam

23 Jazak Yus Afriansyah, "Empat Cara Membangkitkan Potensi Generasi Milenial" Situs 26/4.cara.bangkitkan.potensi.generasi. millineal-kompas.com. di akses pada jam 15:34 Wita tanggal 16 november 2018.

Akhmad Ramidi, Ishak Hariyanto 
perbaikan baik terhdap diri sendiri dan sosial, mengingat di tahun 2018 ini adalah bahwa informasi dan berita yang hoax tidak dapat di sangkal lagi bahwa media sudah terlalu lama disalahgunakan oleh orang-orang yang opportunist demi jabatan, kekuasaaan dan uang semata. Tetapi ada dimensi lain dari media yaitu sebagai alat dahsyat yang dapat memberikan kemudahan dalam berkomunikasi. Apabila remaja kita sekarang ini dapat memfilter sebuah informasi mana yang harus disebar atau tidak tidak sebarkan.

Di era ini segala sesuatu dapat bergerak dengan sangat cepat, dunia menjadi tanpa batas, informasi dapat diperoleh dimana saja dan dari siapa saja. Generasi masa kini harus berusaha dan mampu menjadi bijak bijak terutama dalam menggunakan dalam menggunakan media sosial. Remaja masa kini juga harus mampu beradaptasi dengan dengan cepat, belajar dan menjadi lebih baik dan dapat memecahkan suatu masalah baik di masyarakat maupun untuk Negara. ${ }^{24}$

24 Dini Shanti Purwono, "Peran Dan Tantangan Pemuda Di Era Generasi Milenial" Situs, serikatnews.com/peran-dan-tantanganpemuda-di-era-generasi-milenial/ di akses pada jam 13:51 Wita tanggal 1 desembar 2018.

\section{B. Kajian Generasi Milenial}

Tulisan tentang bimbingan konseling pribadi dan sosial sudah banyak dilakukan oleh peneliti yang melatar belakangi sehingga tulisannya ditulis. Adapun penting kiranya, memaparkan tulisan-tulisan tersebut untuk mengetahui hasil yang telah ditulis dan mengetahui sejauh mana pembahasan tentang bimbingan konseling pribadi dan sosial secara mendalam atau dapat di simpulkan terdapat persamaan dan perbedaan dengan hasil tulisan yang sudah ditulis oleh penulislain. Adapun tulisan-tulisan yang telah dilakukan yang berkaitan dengan bimbingan konseling pribadi dan sosial adalah sebagai berikut:

Pertama, jurnal yang ditulis oleh Noveliyati Sabani Universitas Indonesia dengan judul "Generasi Milenial dan Absuditas Debat Kusir Virtual" dia menjelaskan, debat kusir virtual yang bersifat absurd adalah salah satu gejala yang berkaitan dengan hubungan antara generasi milenial dengan media sosial $^{25}$. Jadi dia membahas generasi milenial dalam ranah ruang lingkup media masa atau sosial sedangkan artikel ini membahas tentang fenomena-fenomena yang terjadi pada generasi milenial.

25 Noveliyanti Sabani, "Generasi Milenial Dan Absurditas Debat Kusir Virtual", Jurnal Informasi Kajian Ilmu Komunikasi, (Vol. 48. No. 1. Thn. 2018). 
Kedua, Egy Novita Fitri dan Marjohan, Universitas Negeri Padang dengan judul "Manfaat Layanan Konseling Kelompok Dalam Menyelesaikan Masalah Pribadi Siswa" dia menjelaskan, pentingnya layanan konseling kelompok dalam menyelesaikan masalah siswa yang extrovert dan diperlukan menyelesaikan masalah siswa tersebut ${ }^{26}$. Jadi dia membahas, tentang masalah yang terjadi kepada siswa yang mempunyai sifat extrovert sedangkan artikel ini membahas tentang kekuatan, kelemahan, ancaman dan peluang remaja di era milenial.

Ketiga, Ardhaneswari Habiba, Mungin Edy Wibowo dan Muhammad Jafar, dalam jurnalbimbingan konseling islam dengan judul "Model Bimbingan Konseling Kelompok Teknik Self Instruction Untuk Meningkatkan Self Confidence Siswa SMP" dia menjelaskan, layanan konseling kelompok sudah dilaksanakan namun masih terfokus pada siswa yang mengalami masalah dan teknik yang digunakanhanyaterkaitteknikdiskusi ${ }^{27}$.

26 Egy Novita Fitri dan Marjohan, "Manfaat Layanan Konseling Kelompok Dalam Menyelesaikan Masalah Pribadi Siswa”, Jurnal Education, (Vol. 2. No. 2. Thn. 2016).

27 Ardhaneswari Habiba. Mungin Edy Wibowo dan Muhammad Jafar, "Model Bimbingan Konseling Kelompok Teknik Self Instruction Untuk Meningkatkan Self Confidence Siswa SMP”,Jurnal Bimbingan Konseling, (Vol. 6. No. 1. Thn. 2017).
Sedangkan artikel ini membahas tentang bimbingan konseling pribadi dan sosial untuk remaja dan teknik yang digunakan adalah teknik dengan pendekatan Alfred adler.

C. Tawaran Desain Bimbingan Pribadi dan Sosial Untuk Remaja di Era Milenial

Dalam memberikan sebuah tawaran untuk remaja di era milenial maka diperlukan sebuah tawaran yang jelas, sebuah model untuk dijadikan sebagai pedoman dalam membangun bertingkah laku dalam keseharian nya, karena kita berbicara masalah manusia yang segala persoalan dan permasalahannya begitu kompleks dan tentu membutuhkan waktu yang lama untuk sama-sama saling memperbaiki baik secara internal dan eksternal pribadi manusia tersebut.

Kekacauan emosi sebagai kegagalan dalam hidup, semua kegagalan seperti neurosis, psikosis, kejahatan, kecanduan minuman keras kenakalan remaja, kecendrungan bunuh diri, kelainan seks dan pelacuran merupakan kegagalan seseorang karena kurangnya memiliki minat sosial. Maka, terapi atau konseling yang dilaksanakan oleh mereka sebenarnya didasakan dari model kependidikan kaena kebanyakan yang terjadi dari hal-hal di dalam kelompok itu adalah proses belajar mengajar mengenai 
pendekatan yang lebih baik dalam menghadapi khidupan dan mereka dapat memperoleh keberhasilan dalam hidupnya. ${ }^{28}$

Adapun Tahap-tahap dalam proses konseling dalam pandangan Alfred Adler yaitu:

1. Tahap membentuk dan memelihara hubungan

Dalam tahap membentuk dan memelihara hubungan didasarkan pada adanya kerjasama, saling menghargai dan bertanggung jawab serta berpartisipasi dengan baik secara individu dan kelompok.

2. Tahap analisis dan penilaian

Tahap ini mempunyai tujuan ada dua yaitu memahami gaya hidup seseorang dan mengamati berbagai gaya hidup yang mempengaruhi perilaku seseorang yang bersangkutan dalam menjalankan kehidupannya.

3. Tahap wawasan

Dalam suasana kelompok tahap wawasan di arahkan membantu seseorang memahami mengapa mereka bisa berbuat demikian sepertimenyimpangdarinormalitas kehidupan sejatinya.

4. Tahap orientasi kembali

28 Edi Kurnanto, Konseling Kelompok, (Bandung, CV Alfabeta, 2013), 52.
Dalam tahapini, peranan kelompok sangat penting, karena kelompok bisa merangsang tindakan dan orientasi yang baru. Dalam kelompok seseorang dapat mengenal bahwa di dalam dirinya terdapat perilaku atau sipat-sipat yang keliru terhadap dirinya dan orang lain. Orientasi kembali merupakan tahap pengambilan tindakan apabila seseorang telah dapat menentukan keputusan dan tujuan-tujuannya telah di perbaiki. ${ }^{29}$

\section{Penutup}

Generasi milenial adalah generasi yang mahir di dalam menggunakan teknologi. Peran dan fungsinya sebagai generasi milenial harus bisa tercipta sebagai generasi agent of change dan harus menjadi orang yang optimis dan tidak mudah untuk berhenti melakukukan langkah-langkah dalam perbaikan baik terhdap diri sendiri dan sosial, mengingat di tahun 2018 ini adalah bahwa informasi dan berita yang hoax tidak dapat di sangkal lagi bahwa media sudah terlalu lama disalahgunakan oleh orang-orang yang opportunist demi jabatan, kekuasaaan dan uang semata. Tetapi ada dimensi lain dari media yaitu sebagai alat dahsyat yang dapat memberikan kemudahan dalam berkomunikasi. Apabila remaja kita sekarang ini dapat

29 Ibid., 53-54.

164 | Generalisasi Bimbingan Konseling Pribadi dan Sosial... 
memfilter sebuah informasi mana yang harus disebar atau tidak tidak sebarkan. Generasi milenial dihadapkan pada kasus tawuran, narkoba, minuman keras, pergaulan bebas, dan pelecehan seksual. Fenomena-fenomena sosial semacam ini harus dianalisis dan dicarikan solusinya, salah satunya melalui pendekatan konseling kelompok Alfred Adler. Adapun hasil

Daftar Pustaka

Hayes, Eileen, Tantrum, Panduan Memahami dan Mengatasi Ledakan Emosi Anak, (Jakarta: Erlangga, 2003)

Prayitno Dan Erman Amti, Dasar-Dasar Bimbingan Konseling, (Jakarta: Pt Rineka Cipta, 2013)

Farid Mashudi, Psikologi Konseling, (Jogjakarta: Ircisod Penerbit, 2012)

Syamsu Yusuf, Bimbingan Dan Koseling Perkembangan: Suatu Pendekatan Komprehensif, (Bandung: PT. Refika Aditama, 2017)

Naskah Sub Direktorat Statistik Politik Dan Keamanan, Jakarta: Badan Pusat Statistik Indonesia, 2017 analisis konseling kelompok dalam pandangan Alfred Adler yakni: a. tahap membentuk dan memelihara hubungan, b. tahap analisis dan penilaian,c.tahapwawasandan, d.tahap orientasi kembali. Terapi konseling semacam ini harus dilaksanakan sebagai model pendidikan dalam suatu kelompok.
Samuel T. Gladding, Konseling Profesi Yang Menyeluruh, (Jakarta Barat:PT Indeks, 2015)

Jazak Yus Afriansyah, "Empat Cara Membangkitkan Potensi Generasi Milenial” Situs 26/4. cara.bangkitkan.potensi.generasi. millineal-kompas.com. di akses pada jam 15:34 Wita tanggal 16 november 2018

Dini Shanti Purwono, "Peran Dan Tantangan Pemuda Di Era Generasi Milenial" Situs, serikatnews.com/peran-dantantangan-pemuda-di-era-generasimilenial/ di akses pada jam 13:51 Wita tanggal 1 desembar 2018

Noveliyanti Sabani, "Generasi Milenial Dan Absurditas Debat Kusir Virtual”, Jurnal Informasi Kajian 
al Tazkiah, Volume 7, No. 2, Desember 2018

Ilmu Komunikasi, (Vol. 48. No. 1. ArdhaneswariHabiba.Mungin Edy Wibowo Thn. 2018)

Egy Novita Fitri dan Marjohan, "Manfaat Layanan Konseling Kelompok Dalam Menyelesaikan Masalah Pribadi Siswa”, Jurnal Education, (Vol. 2. No. 2. Thn. 2016) dan Muhammad Jafar, "Model Bimbingan Konseling Kelompok Teknik Self Instruction Untuk Meningkatkan Self Confidence Siswa SMP”,Jurnal Bimbingan Konseling, (Vol. 6. No. 1. Thn. 2017) EdiKurnanto, Konseling Kelompok,(Bandung, CV Alfabeta, 2013) 